\title{
前交通動脈瘤に対する開頭クリッピング術 一当院でのアプローチ法選択についての検討一
}

\author{
出雲 剛, 松尾 孝之, 林 健太郎, 日宇 健 \\ 諸藤 陽一, 堀江 信貴, 永田泉
}

\section{Surgical Treatment for Anterior Communicating Artery Aneurysms}

Tsuyoshi Izumo, M.D., Ph.D., Takayuki Matsuo, M.D., Ph.D., Kentaro Hayashi, M.D., Ph.D., Takeshi Hiu, M.D., Ph.D., Yoichi MorofuJI, M.D., Ph.D., Nobutaka Horie, M.D., Ph.D., and Izumi Nagata, M.D., Ph.D.

Department of Neurosurgery, Nagasaki University Graduate School of Biomedical Sciences, Nagasaki, Japan

Summary: We evaluate our surgical approach for the treatment of anterior communicating artery (AcomA) aneurysms.

Between March 2004 and August 2012, 56 cases with AcomA aneurysms were treated by clipping at our institute and retrospectively reviewed about surgical approaches and postoperative complications.

Of the 56 patients with AcomA aneurysms, eight patients were treated through the anterior interhemispheric approach, and 48 patients were treated through the pterional approach (PA). In 38 of the 48 cases clipped through PA, the open A2 fork side were chosen, and 10 of the 48 PA cases were treated from the closed A2 fork side. Of the 10 cases, four had open A2 fork to dominant A1 side ("reversed-torsion AcomA"), four were dorsal projection AcomA aneurysms, one had lateralized AcomA, and one had multiple aneurysms treated with one operative procedure. For high-positioned, relatively large and other dorsal projection aneurysms, anterior interhemispheric approach were chosen. All aneurysms were satisfactorily obliterated, and there were no perforator infarctions.

Selecting the appropriate approach based on the size and height of the aneurysm and morphology of AcomA complex provided good postoperative results.

\section{Key words:}

- Acom aneurysm

- surgical approach

Surg Cereb Stroke (Jpn) 42: 270-277, 2014

\section{はじめに}

前交通動脈瘤 (AcomA An.) はわれわれ脳神経外科医が 臨床にて経験する頻度の高い脳動脈瘤の 1 つであり, 多部
位の動脈瘤に比して破裂する危険性が比較的高い ${ }^{14)}$ ことか ら，未破裂瘤として予防的に治療される機会も多い脳動脈 瘤である。開頭クリッピング術においては pterional approach $(\mathrm{PA})^{15)}$ と anterior interhemispheric approach

長崎大学 脳神経外科(受稿日 2013.8.14)(脱稿日 2014.1.20)〔連絡先： $\overline{7} 852-8501$ 長崎市坂本 1-7-1 長崎大学 脳神経外科 出雲 剛] [Address correspondence: Tsuyoshi Izumo, M.D., Department of Neurosurgery, Nagasaki University Graduate School of Biomedical Sciences, 1-7-1 Sakamoto, Nagasaki 852-8501, Japan] 


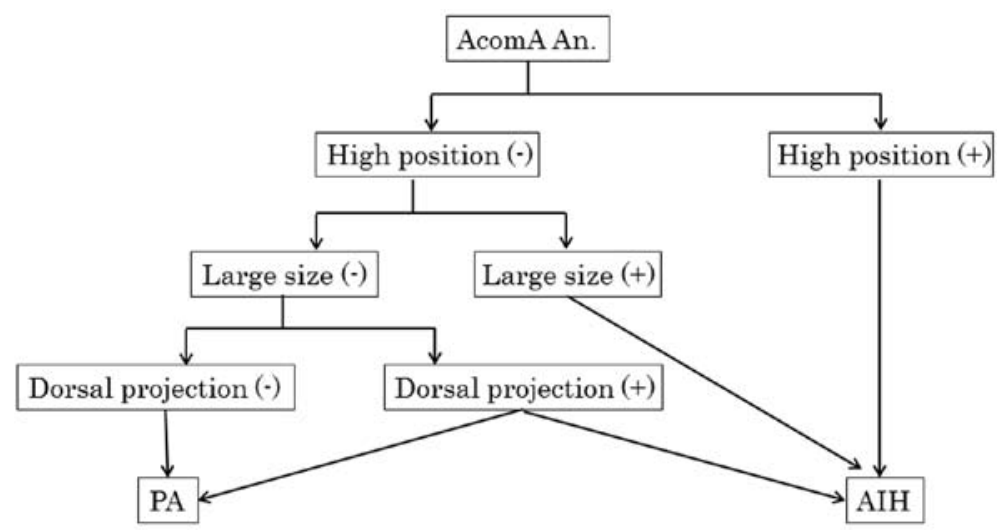

Fig. 1 Selection of surgical approach for AcomA An. AcomA An.: anterior communicating artery aneurysm, PA: pterional approach, $\mathrm{AlH}$ : anterior interhemispheric approach

$(\mathrm{AIH})^{16)}$ のいずれかが選択されることがほとんどである. anterior communicating artery complex (AcomA complex)からは hypothalamic arteryを代表とする穿通枝が 分岐し，その障害により記銘力低下や精神症状などを呈す

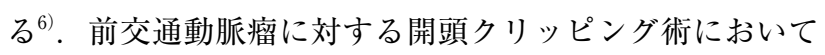
はこれら穿通枝の温存を図るべく, AcomA complex およ び動脈瘤, 穿通枝が十分観察可能でなおかつ操作性の高い アプローチ法選択が重要となる ${ }^{5)}$. 当施設で開頭クリッピ ング術を施行した前交通動脈瘤症例についてアプローチ法 選択について解説し, 手術成績および術後合併症について 検討を行った.

\section{対象・方法}

2004 年 3 月から 2012 年 8 月までに開頭クリッピング術 を施行した前交通動脈瘤連続 56 例 (未破裂 53 例・破裂 3 例)について検討した. 動脈瘤の高位評価については, 前 床突起から動脈瘤頚部上部までの高さが $13 \mathrm{~mm}$ 以上のも のを高位動脈瘤とした. 動脈瘤の突出方向については鈴木 $ら^{13)}$ の報告をもとにCTA もしくは DSA を元に側面から Acomを中心として 0 時から 5 時を anterior type, 9 時か ら 12 時を dorsal type, 5 時から 9 時を inferior type と した. 術後穿通枝梗塞の評価は CT もしくは MRIにて行っ た.

当院での AcomA An.クリッピング術におけるアプロー チ選択：高位病変やサイズが大きめであるもの, 一部の dorsal projectionの AcomA An.に対してはAIH を選択 する. それ以外の AcomA An.についてはPA を選択する

(Fig. 1). PA における術側決定は左右 $\mathrm{A} 2$ の前後に差が ない症例では非優位側から, AcomA complex が A1 優位 側にねじれる，いわゆる“逆捻れ”の場合や dorsal projectionの一部ではより A2 が前方に位置する側から，
AcomA complex がどちらかに偏在する症例では偏在側か らのPA を選択し，上記のいずれでもない AcomA An.に ついては A2 がより後方に位置する側からの PA を選択す る.

\section{結果 (Table 1)}

くも膜下出血発症例が 3 例で未破裂 AcomA An. が 53 例, 2 例において AcomA に 2 力所の動脈瘤を認め, 合計 58 AcomA An.に対する手術を行った. AcomA An. 以 外の多発性脳動脈瘤は 12 症例に認められた。動脈瘤のサ イズは最大径 1.5-16 mm (平均 $6.3 \mathrm{~mm}$ ) であった. 前床突 起から動脈瘤頝部上部までの高さは 1.5-16 mm (平均 6.6 $\mathrm{mm}$ )であった. 突出方向は anterior type 44 動脈瘤, dorsal type 12 動脈瘤, inferior type 2 動脈瘤であった。

A1 dominancy については右側優位が 38 例 (58\%), 左 側優位が 10 例 (18\%), 左右差を認めない症例が 8 例 (14\%) であった．両側 A2 近位部走行の前後関係は右 A2 が後方 であるものが 30 例 (54\%), 左 A2 が後方であるものが 25 例 (45\%), 前後関係に左右差がないものが 1 例 ( $2 \%$ )であっ た.

\section{アプローチ法選択の分析結果}

PA が選択された症例は 48 例であった，術側について は A2 が後方に位置する側が 38 例であった. A2 が前方に 位置する側が術側に選択されたものは 10 例であり, その 要因としては AcomA complex が A1 優位側に捻れた, い わゆる “逆捻れ”が 4 例, dorsal projection が 4 例, AcomA complexの偏在により近い術側が選択された結果 が 1 例, AcomA An. 以外の多発性脳動脈瘤の同時処置の ためが 1 例であった. AIHA が選択された症例は 8 例であ り, その選択要因としては dorsal projectionの動脈瘤が 5 
Table 1

\begin{tabular}{|c|c|c|c|c|c|c|c|c|c|}
\hline $\begin{array}{l}\text { No. } \\
\text { of case }\end{array}$ & Sex & Age & $\begin{array}{l}\text { Concomitant } \\
\text { aneurysms }\end{array}$ & $\begin{array}{l}\text { Height from anterior } \\
\text { clinoid process }(\mathrm{mm})\end{array}$ & Approach & $\begin{array}{l}\text { Dominancy } \\
\text { of } A 1\end{array}$ & $\begin{array}{l}\text { Posterior side of } \\
\text { proximal A2 }\end{array}$ & $\begin{array}{l}\text { Aneurysmal } \\
\text { projection }\end{array}$ & Size \\
\hline 1 & M & 63 & & 2 & rt PA & It & $\mathrm{rt}$ & anterior & 1.5 \\
\hline 2 & $M$ & 48 & & 12 & rt PA & equal & $\mathrm{rt}$ & anterior & 10 \\
\hline 3 & $\mathrm{~F}$ & 49 & & 8 & rt PA & It & $\mathrm{rt}$ & anterior & 5 \\
\hline 4 & $\mathrm{~F}$ & 48 & & 3.5 & rt PA & It & $\mathrm{rt}$ & anterior & 5 \\
\hline 5 & $M$ & 65 & & 10 & rt PA & It & It & anterior & 5.8 \\
\hline 6 & $\mathrm{~F}$ & 48 & & 5 & rt PA & It & It & anterior & 5.3 \\
\hline 7 & M & 45 & & 5.5 & rt PA & equal & $\mathrm{rt}$ & anterior & 8.2 \\
\hline 8 & $\mathrm{~F}$ & 70 & & 10 & AlH & It & It & dorsal & 6.4 \\
\hline 9 & $\mathrm{~F}$ & 56 & & 8 & It PA & $\mathrm{rt}$ & It & anterior & 5 \\
\hline 10 & $\mathrm{~F}$ & 69 & distal ACA, bilateral MCA & 2 & rt PA & It & $\mathrm{rt}$ & anterior & 13.6 \\
\hline 11 & M & 63 & & 6 & AlH & It & equal & dorsal & 5 \\
\hline 12 & $\mathrm{~F}$ & 67 & & 5 & It PA & equal & It & anterior & 13 \\
\hline 13 & $\mathrm{~F}$ & 74 & & 3 & rt PA & It & $\mathrm{rt}$ & anterior & 3.3 \\
\hline 14 & $\mathrm{~F}$ & 62 & & 6 & rt PA & It & $\mathrm{rt}$ & anterior & 6 \\
\hline 15 & $\mathrm{~F}$ & 66 & & 3 & It PA & It & It & anterior & 8.6 \\
\hline 16 & $\mathrm{~F}$ & 72 & rt MCA & 8 & rt PA & It & $\mathrm{rt}$ & anterior & 10 \\
\hline 17 & M & 50 & It MCA & 8 & It PA & $\mathrm{rt}$ & It & anterior & 8 \\
\hline 18 & $\mathrm{~F}$ & 42 & & 4 & It PA & $\mathrm{rt}$ & $\mathrm{rt}$ & inferior & 7 \\
\hline $19^{*}$ & M & 45 & & 5 & rt PA & It & $\mathrm{rt}$ & anterior & 5.3 \\
\hline 20 & $\mathrm{~F}$ & 66 & & 10 & $\mathrm{AlH}$ & equal & equal & dorsal & 6.5 \\
\hline 21 & $\mathrm{~F}$ & 67 & & 8 & rt PA & It & $\mathrm{rt}$ & inferior & 7.5 \\
\hline 22 & $\mathrm{~F}$ & 67 & ICA & 7.5 & It PA & $\mathrm{rt}$ & $\mathrm{rt}$ & dorsal & 11 \\
\hline 23 & $\mathrm{~F}$ & 42 & & 2.5 & rt PA & It & $\mathrm{rt}$ & anterior & 4.5 and 2.5 \\
\hline 24 & $\mathrm{~F}$ & 61 & It ICA & 7.1 & It PA & It & It & anterior & 3.5 \\
\hline $25^{*}$ & $\mathrm{~F}$ & 76 & & 4.5 & rt PA & It & It & dorsal & 1.5 \\
\hline 26 & M & 67 & rt MCA & 6.5 & rt PA & equal & $\mathrm{rt}$ & anterior & 15 \\
\hline 27 & $\mathrm{~F}$ & 62 & & 6.5 & rt PA & It & It & anterior & 5.5 \\
\hline 28 & M & 43 & & 3.5 & rt PA & It & $\mathrm{rt}$ & anterior & 5.3 \\
\hline 29 & M & 64 & & 6 & It PA & It & It & anterior and dorsal & 16 and 8.3 \\
\hline 30 & M & 55 & & 12 & rt PA & $\mathrm{rt}$ & $\mathrm{rt}$ & anterior & 4 \\
\hline 31 & $\mathrm{~F}$ & 46 & rt MCA & 5.5 & rt PA & It & $\mathrm{rt}$ & anterior & 9.2 and 4.0 \\
\hline 32 & $M$ & 31 & & 5.5 & rt PA & $\mathrm{rt}$ & It & dorsal & 4.3 \\
\hline $33^{*}$ & $\mathrm{~F}$ & 65 & & 9.5 & rt PA & It & It & dorsal & 3.3 \\
\hline 34 & $\mathrm{~F}$ & 59 & & 12.5 & rt PA & equal & $\mathrm{rt}$ & anterior & 1.5 \\
\hline 35 & M & 67 & & 5 & It PA & equal & It & anterior & 7 \\
\hline 36 & $\mathrm{~F}$ & 71 & & 13 & $\mathrm{AlH}$ & It & $\mathrm{rt}$ & anterior & 5.2 \\
\hline 37 & $\mathrm{~F}$ & 64 & It ICA & 5.5 & It PA & It & It & anterior & 4.5 \\
\hline 38 & M & 69 & rt MCA & 7.5 & rt PA & equal & $\mathrm{rt}$ & anterior & 3.4 \\
\hline 39 & M & 65 & & 6 & It PA & It & It & anterior & 8 \\
\hline 40 & $\mathrm{~F}$ & 66 & & 5 & rt PA & $\mathrm{rt}$ & $\mathrm{rt}$ & anterior & 4.9 \\
\hline 41 & $\mathrm{~F}$ & 58 & & 2.5 & rt PA & It & $\mathrm{rt}$ & anterior & 6.5 \\
\hline 42 & $\mathrm{~F}$ & 44 & It ICA & 5.5 & It PA & It & It & anterior & 3.2 \\
\hline 43 & $M$ & 62 & & 16 & $\mathrm{AlH}$ & It & It & anterior & 4.1 \\
\hline 44 & $M$ & 57 & It ICA & 6.7 & It PA & It & It & anterior & 3.1 \\
\hline 45 & $\mathrm{~F}$ & 53 & & 7.8 & It PA & It & It & anterior & 5.5 \\
\hline 46 & $M$ & 74 & & 6 & rt PA & It & $\mathrm{rt}$ & anterior & 4.1 \\
\hline 47 & $\mathrm{~F}$ & 49 & & 3 & It PA & $\mathrm{rt}$ & It & anterior & 4.8 \\
\hline 48 & $M$ & 68 & & 3 & $\mathrm{AlH}$ & It & It & dorsal & 5 \\
\hline 49 & $\mathrm{~F}$ & 61 & & 6.7 & rt PA & $\mathrm{rt}$ & It & anterior & 9.1 \\
\hline 50 & $\mathrm{~F}$ & 53 & & 13 & AlH & It & $\mathrm{rt}$ & anterior & 13 \\
\hline 51 & $\mathrm{~F}$ & 61 & & 3.5 & rt PA & $\mathrm{rt}$ & $\mathrm{rt}$ & anterior & 5.2 \\
\hline 52 & $\mathrm{~F}$ & 52 & It ICA & 8 & It PA & It & $\mathrm{rt}$ & anterior & 9.2 \\
\hline 53 & $\mathrm{~F}$ & 77 & & 3.5 & rt PA & It & $\mathrm{rt}$ & anterior & 3.5 \\
\hline 54 & $M$ & 64 & & 14 & AlH & It & It & dorsal & 4 \\
\hline 55 & $\mathrm{~F}$ & 74 & rt MCA & 1.5 & rt PA & equal & $\mathrm{rt}$ & anterior & 3.5 \\
\hline 56 & $\mathrm{~F}$ & 68 & & 5.5 & It $\mathrm{PA}$ & It & It & anterior & 15.5 \\
\hline
\end{tabular}

*: subarachnoid hemorrhage patient, A1: A1 segment of anterior cerebral artery, A2: A2 segment of anterior cerebral artery, ACA: anterior cerebral artery, MCA: middle cerebral artery, ICA: internal cerebral artery, rt: right It: left, PA: pterional approach, AlH: anterior interhemispheric approach 


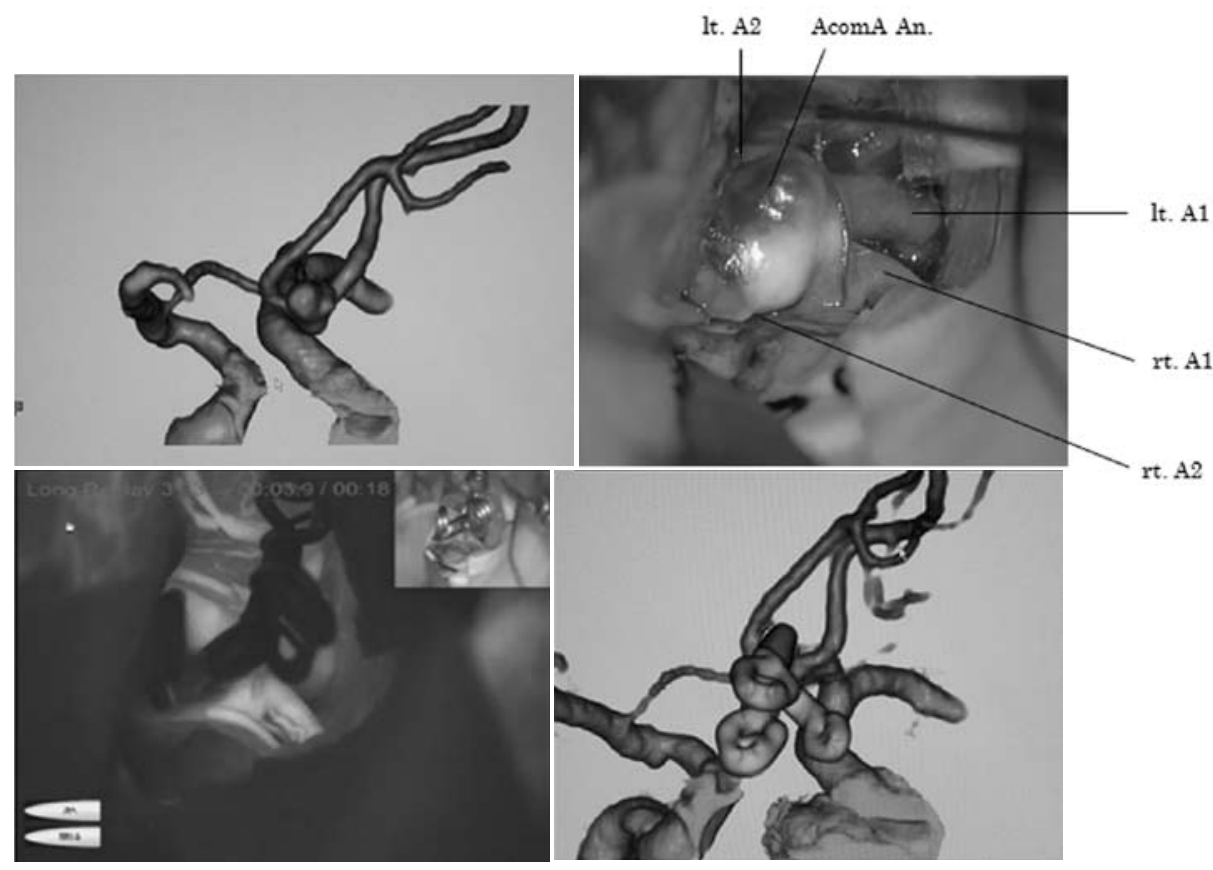

Fig. 2 A 74-year-old man with an enlarging AcomA An. CTA showed that an AcomA complex was open to right side (A). Rt. PA was performed. Intraoperative findings clearly revealed an AcomA complex and An. (B), complete obliteration of the An. and preservation of each branches (C), confirmed by postoperative CTA (D).

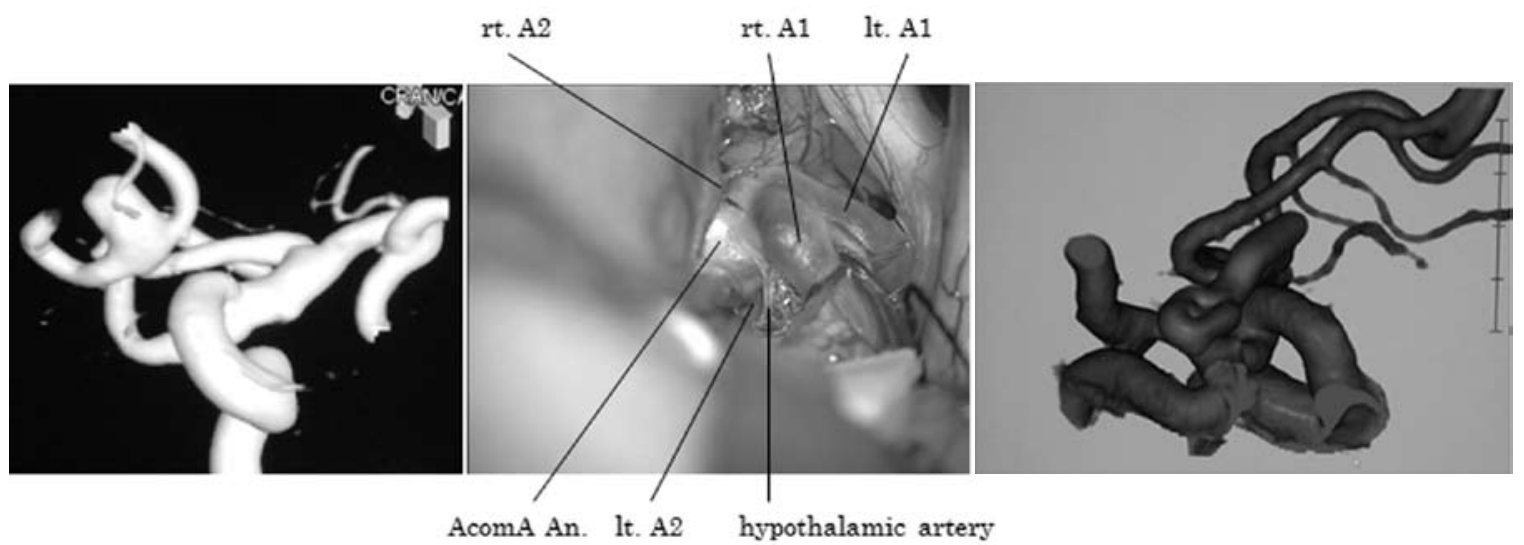

Fig. 3 A 62-year-old woman with an AcomA An. CTA showed that an AcomA complex had reversed torsion (A). Rt. PA was performed. Intraoperative findings clearly revealed an AcomA complex, hypothalamic artery, and An. (B). A complete obliteration of the An. and preservation of each branches was confirmed by postoperative CTA (C).

例，高位の動脈瘤が 4 例，比較的大きなサイズの動脈瘤が 1 例であった(選択要因の重複あり)。術中は全例において AcomA complex およびAcomA An. に対する十分な観察 が可能で, クリッピングを施行した。 術後に穿通枝閉塞に よる脳梗塞は認めなかった. case No. 52 では合併する右 C2 動脈瘤の術中破裂に対して頝部内澒動脈で proximal control を行った結果, 術後同部位の解離に伴う閉塞によ り右中大脳動脈領域に広範囲な梗塞による左片麻瘻を後遺
し modified Rankin Scale 3 にて転院となった。 その他の 症例は modified Rankin Scale 0-1にて自宅退院となった.

\section{代表症例提示}

〈症例 1〉A2 後方側からのPA（case No. 46）：74歳男性, bleb を伴い最大径 $6 \mathrm{~mm}$, anterior projectionの未破裂 AcomA An. の症例. A1 dominancy は右優位で左 A2 上 りも右 A2 が後方に位置する(Fig. 2A). 右 PA にてクリッ 


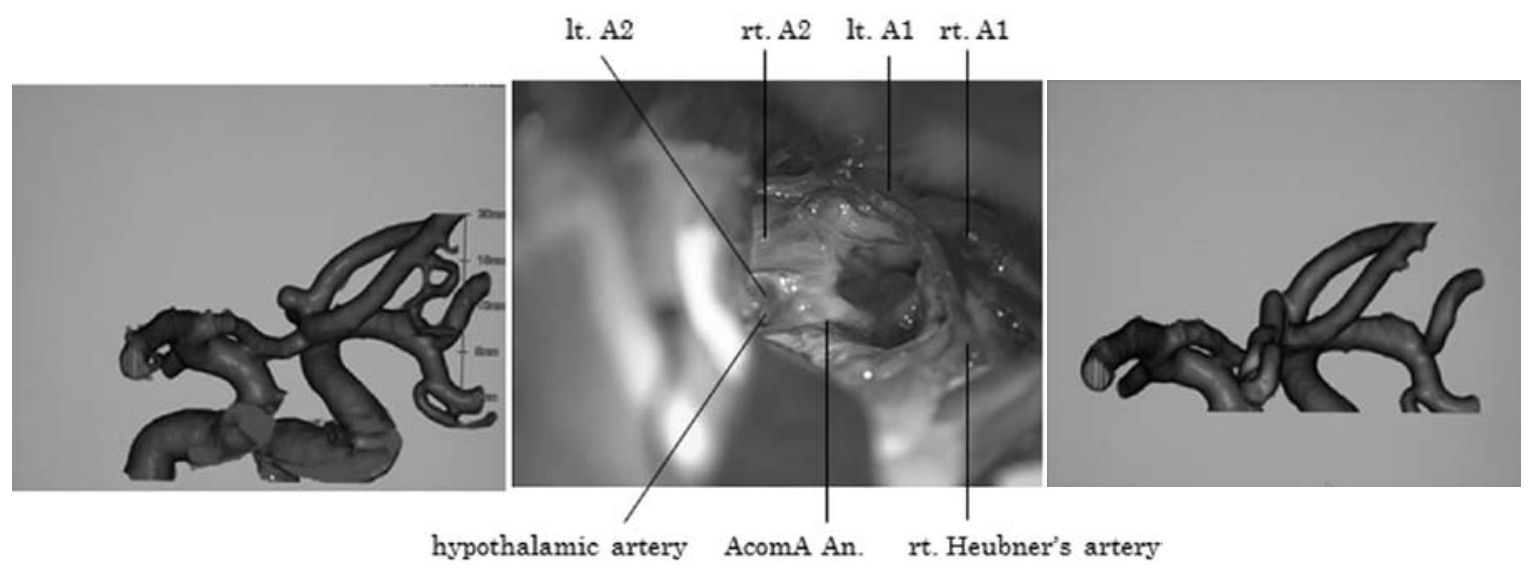

Fig. 4 A 65-year-old woman with a dorsal projection AcomA An. (A). An AcomA plane was open to left side. Rt. PA was performed. Intraoperative findings clearly revealed an AcomA complex, hypothalamic artery, and An. (B). A complete obliteration of the An. and preservation of each branches was confirmed by postoperative CTA (C).

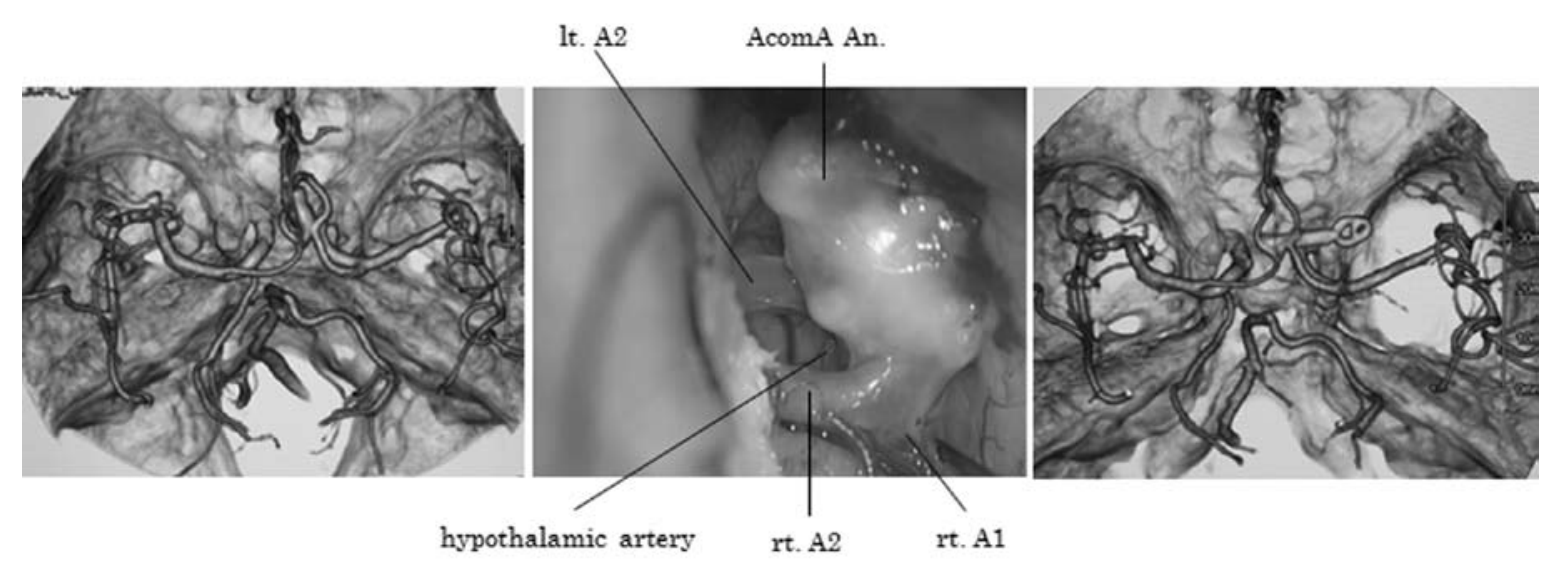

Fig. 5 A 61-year-old woman with an anterior projection AcomA An. (A). An AcomA complex was lateralized to right side. Rt. PA was performed. Intraoperative findings clearly revealed an AcomA complex, hypothalamic artery, and An. (B). A complete obliteration of the An. and preservation of each branches was confirmed by postoperative CTA (C).

ピングを行った，右直回を一部吸引して AcomA complex を十分確認できた(Fig. 2B). 合計 3 個のクリップにて closure line 形成的にクリッピングを行い, インドシアン ニングリーン蛍光ビデオ血管撮影にて動脈瘤内血流消失お よび穿通枝を含めたAcomA complexの血流温存を確認 した Fig. 2C). 術後頭部 3 次元 CT 血管造影法 (3D-CTA) でも動脈瘤消失と血管温存が確認された(Fig. 2D).

〈症例2〉A2 前方側からのPA（case No. 27）：62歳女性, 左 A1 優位で AcomA complex が優位側に極端に傾く, い わゆる“逆捻れ”に発生したAcomA An. 症例(Fig. 3A). 右 PA にてクリッピング術を行った．視床下部動脈起始部 を含むAcomA complexが十分に確認され(Fig. 3B)，ク リッピングを行った. 術後 CTA にて血管温存と動脈瘤消 失を確認した(Fig. 3C).
〈症例3〉A2後方側からのPA（case No. 33）：65歳女性, dorsal projection の AcomA An.の症例. A2 近位部は右 が前方で左が後方(Fig. 4A). 右 PA を選択し右 A1-A2 junction と直回の間を剥離したのちに, 直回を一部吸引除 去して視野を拡大すると穿通枝を含めた AcomA complex と動脈瘤が確認できた(Fig. 4B)，術後 CTA にて血管温 存と動脈瘤消失を確認した (Fig. 4C).

〈症例4〉A2後方側からのPA（case No. 49）：61歳女性, 前方突出で A2 近位部は左がより後方に位置していたが, AcomA complex は右に偏奇しており (Fig. 5A), 左 PA では操作野が梁く遠くなることが予想されたために右 PA にて手術を行った．動脈瘤ドームは視交叉に癒着埋没して おり, ドーム全体の剥離はリスクが高いと判断したが, AcomA complex の確認操作は比較的浅い操作野にて可能 


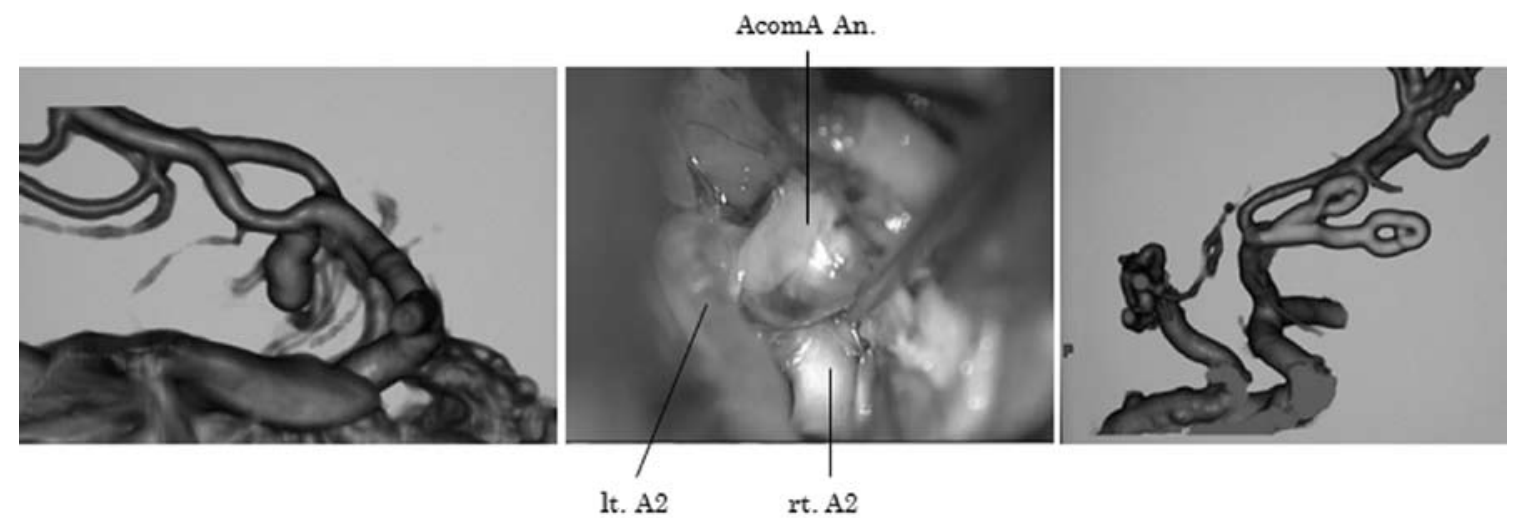

Fig. 6 A 53-year-old woman with a large and high positioned AcomA An. (A). AlHA was performed. Intraoperative findings revealed an AcomA complex and An. (B). A complete obliteration of the An. and preservation of each branches was confirmed by postoperative CTA $(\mathbf{C})$.

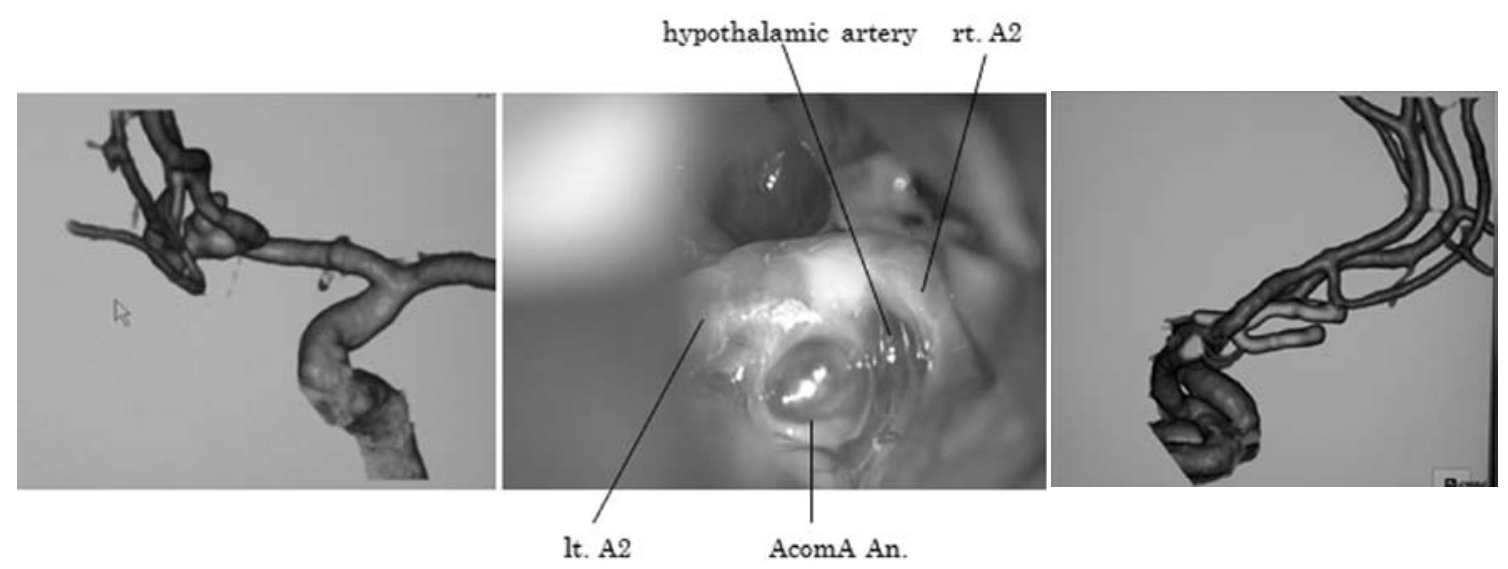

Fig. 7 A 64-year-old woman with a dorsal projection AcomA An. (A). AlHA was performed. Intraoperative findings revealed an AcomA complex, hypothalamic artery, and An. (B). A complete obliteration of the An. and preservation of each branches was confirmed by postoperative CTA (C).

であり(Fig. 5B), クリッピングを施行した. 術後 CTA にて血管温存と動脈瘤消失を確認した(Fig. 5C).

〈症例 5〉AIHA (case No. 50)：53 歳女性, AcomA An. の最大径は $13 \mathrm{~mm}$ と比較的大きく, 動脈瘤頚部上部 から前頭蓋底までが $13 \mathrm{~mm}$ の高位 AcomA An. (Fig. 6A) であり AIHを選択した. AcomA complexを十分確認(Fig. 6B)したのちにクリッピングを施行した. 術後 CTA にて 血管温存と動脈瘤消失を確認した (Fig. 6C).

〈症例 6〉AIH (case No. 54)：64 歳女性, dorsal projectionの AcomA An. で, 動脈瘤澒部上部から前頭蓋底 までが $14 \mathrm{~mm}$ の高位動脈瘤(Fig. 7A)であり AIHA を選 択した. hypothalamic arteryを含むAcomA complex を 十分確認(Fig. 7B) したのちにクリッピングを施行した. 術後 CTAにて血管温存と動脈瘤消失を確認した (Fig. 7C).
考察

AcomA complex においては左右 A1 の優位性やそれに 伴う左右 A2 の前後関係の要因や, 近傍血管の破格を認め ることが比較的多い部位 ${ }^{13)}$ である。また，この部位からは recurrent artery of Heubner やhypothalamic artery が 分岐しており，それらの閉塞により前者では強い不全麻痺 や優位半球の場合には失語症, 後者では高度の記銘力障害 を呈する ${ }^{6)}$. AcomA An. に対するクリッピング術におい てはこれらの分枝・穿通枝を確実に温存することが重要と なり, AcomA complex が十分に確認可能でなおかつ操作 性の高いアプローチ選択が重要となる ${ }^{5)}$. AcomA An.に 対する手術では $\mathrm{PA}^{15)}$ と $\mathrm{AIH}^{16)}$ のいずれかが選択されるこ とがほとんどであり，それぞれの術者のアプローチに対す る習熟度やAcomA complex の形状・動脈瘤のサイズや 


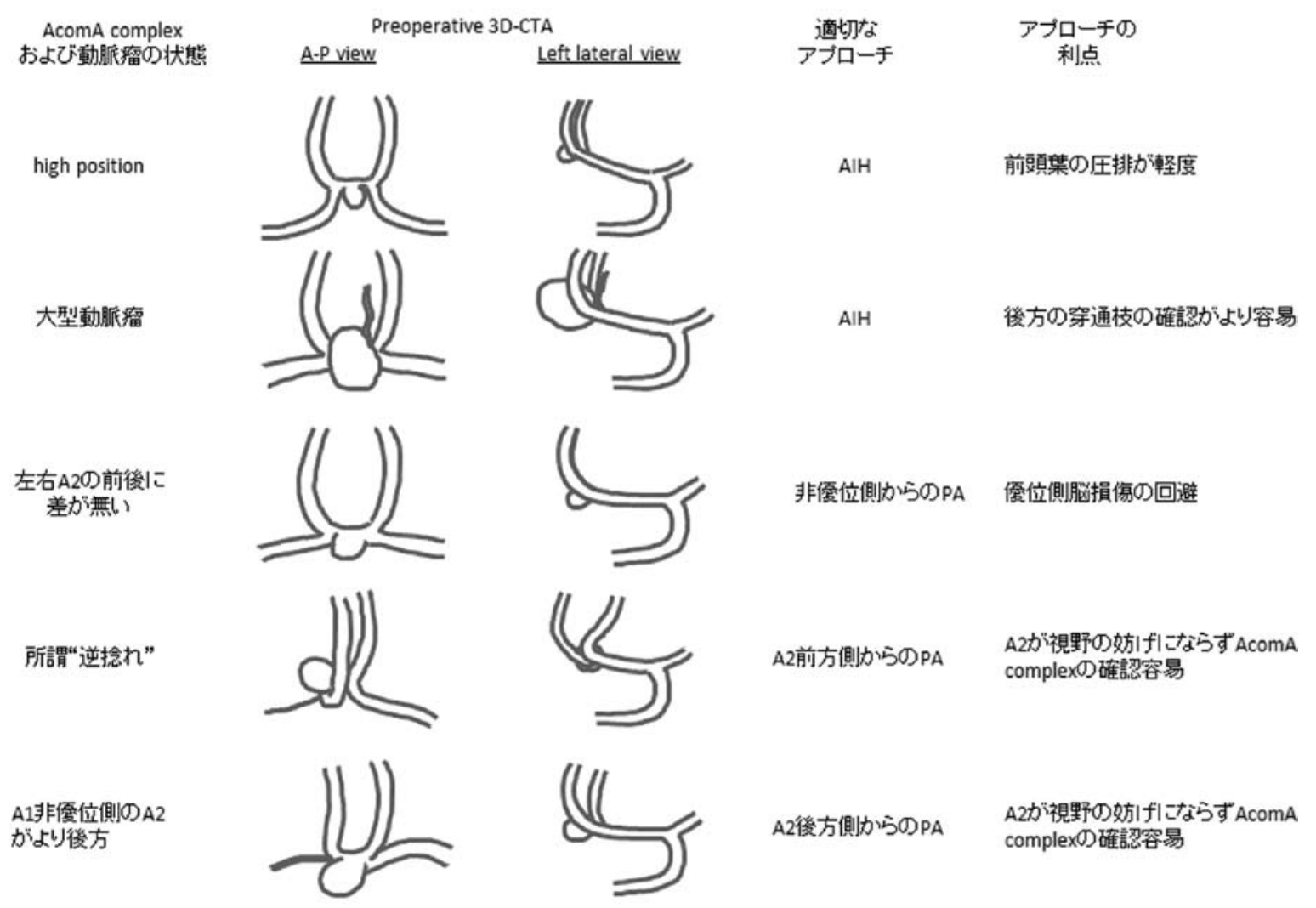

Fig. 8 Schematic representation of selection of surgical approach for AcomA An.

AcomA An.: anterior communicating artery aneurysm, PA: pterional approach, $\mathrm{AlH}$ :

anterior interhemispheric approach

高位などによるさまざまな要因にてアプローチが選択され ている。当科に扔ける AcomA An. に対するアプローチ 法選択の方針とその利点について Fig. 8 に記した.

高位またはサイズの大きな AcomA An.に対するクリッ ピング術においては AIH が絶対的適応となる ${ }^{9) 17)}$. 高位 AcomA An.に対してPA で手術を行うと必然的に前頭葉 の強い牽引が必要となり, 術後の脳挫傷の発生が危惧され る ${ }^{12)}$ 。また，大きなAcomA An.に打いてはPAでは AcomA complex の十分な確認が困難であり, 穿通枝障害 の発生が危惧されるが，AIH であればサイズが大きな AcomA An.に拈いても AcomA complex が十分確認可能 である.また，A3-A3 bypass併用下に母血管閉塞を行う 必要性が生じることもあるため ${ }^{11}, \mathrm{AIH}$ が絶対的適応と 考える。われわれのシリーズでも高位病変・比較的大きな AcomA An. に対して AIH を選択し, 合併症なく良好な 動脈瘤閉鎖が可能であった.

hypothalamic arteryは AcomA complexの上部から分 岐する頻度が高く ${ }^{6)}$, dorsal projectionの動脈瘤では同一 方向への走行となるため, この向きの AcomA An.の手 術においてはその温存に特に注意が必要となる ${ }^{8)}$. dorsal projectionの AcomA An. に対してはAIHA が絶対的適
応との報告を認める ${ }^{10)}$ が，その一方で PA にて処置が可能 との報告も認められる212). われわれは dorsal projection のAcomA An.においてはPAを選択することを基本とし， 高位病変などその他の要因の合併にて AIH を選択するこ ともある. dorsal projectionの AcomA An.に対してPA を行う際の side selectionにおいては, 左右 A2 の前後関 係が重要となる．A2 近位部が前に位置する側からのアプ ローチとし，アプローチ側の A1-A2 junction と直回の間 を剝離しここの間から AcomA complex およびAcomA An. を観察する．必要に応じて直回を一部吸引除去するこ とで十分に視野を確保することも必要となる。一方で dorsal projectionの動脈瘤に対して A2 後方からのPA を 選択した場合にはアプローチ側の A2 が視野の妨げとな り，十分なAcomA complex と動脈瘤および穿通枝確認 が困難となるので注意が必要である.

これらサイズの大きい・高位病変・dorsal projectionの AcomA An. 以外においては, PAのみを選択することで も安全確実なクリッピング術が可能であるが, 十分な AcomA complexの確認のためには side selectionが重要 であることが強調されている(12)12). AcomA An.の症例に おいては A1 dominancy が認められることが多く, 優位 
側の A1-A2 junction ${ }^{6)}$ や A1-A2 angle がより狭い側に動 脈瘤が発生しやすい7)とされる。また，A1 dominancyの 程度により左右 A2 の前後関係も影響を受け, side selectionに打いては術前の画像診断による詳細な検討が必要と なる. AcomA complexはA2 がより後方に位置する方向 からの確認の方が $\mathrm{A} 2$ 前方側からの確認よりも容易であ り，通常は A2 がより後方に位置する側からのPAを選択 する。一方で, A1 dominancyが極端である場合には AcomA complex がA1 優位側に傾く, いわゆる “逆捻れ” を呈するが5)，このような症例において A2 がより後方に 位置する側からのPAにて手術を行うと, 動脈瘤を AcomA complex 越しに観察することとなり，操作野が非 常に手狭になるか，アプローチ側の前頭葉を強く率引する ことによる脳損傷のリスクが高くなると考えられる．動脈 瘤は A1 非優位側に突出することにより，A2 がより前方 に位置する側からのPAにて AcomA complex と動脈瘤 の確認がより容易になる. AcomA complex が極端に左右 どちらかに偏在する場合には, 偏在する side からの PA を行うことで, より浅い操作野での AcomA complex の 確認が可能となる，逆に偏在する対側からのPAでは深い 操作野での動脈瘤周囲の確認が必要となり, 困難な操作と なりうることが想定される. われわれの今回のシリーズで も同様の side selection を行うことで, 十分なAcomA complex の確認が可能となり, 結果術後穿通枝梗塞の発生 は認められず，良好な動脈瘤閉鎖が可能であった。

AcomA An. が下向きに突出する際には視神経との癒着 から対側の $\mathrm{A} 1$ の確保にこつを要することがある．早期の proximal controlのためには両側 A1の確保が重要である. 動脈瘤ドームが視神経や視交叉に癒着する場合, 対側 A1 が直線状に走行する症例においては lamina terminalis cisternにてアプローチ側 A1 から動脈瘤頚部を超えて対 側 A1にアプローチし確保する。 また, 対側 A1 が dorsal convexの走行をとる場合には両側 A2 近位および AcomA complex の上部にて対側 A1 を同定することで, 早期の proximal control が可能となる.

\section{まと め}

AcomA An.に対する開頭クリッピング術においては, AcomA complex の形態や瘤の高さおよび大きさから適切 なアプローチ法を選択することで安全な手術が遂行できる と考えられた。

本論文の要旨は, 第 42 回日本脳卒中の外科学会 $(2012$ 年 3 月 22 日, 東京)において発表した.

\section{文献}

1) Agrawal A, Kato Y, Chen L, et al: Anterior communicating artery aneurysms: an overview. Minim lnvasive Neurosurg 51: 131-135, 2008

2) Chen L, Agrawal A, Kato Y, et al: Role of aneurysm projection in "A2" fork orientation for determining the side of surgical approach. Acta Neurochir 151: 925-933, 2009

3）藤本康裕, 池田宏也, 山本 聡：Pterional approach によ る前交通動脈瘤の手術一術前脳血管撮影と術中局所解剖に よる接近法の検討一. 脳卒中の外科 19: 35-39, 1991

4) Gonzalez-Darder JM: ACoA angle measured by computed tomographic angiography and its relevance in the pterional approach for ACoA aneurysms. Neurol Res 24: 291-295, 2002

5）飯原弘二, 永田 泉：未破裂脳動脈瘤に対する外科的治療. 脳神経外科学大系 8 出血性脳血管障害, 東京, 2004, pp278-263

6）井上 亨, 福井仁士, Day AL：前交通動脈および前交通動 脈の微小外科解剖。顕微鏡下手術のための脳神経外科解剖 III 一脳槽, 脳裂と脳溝一, サイメッド・パブリケーション ズ, 東京, 1991, pp31-38

7) Kasuya H, Shimizu T, Nakaya K, et al: Angles between A1 and A2 segments of the anterior cerebral artery visualized by three-dimensional computed tomographic angiography and association of anterior communicating artery aneurysms. Neurosurgery 45: 89-94, 1999

8）斎藤隆史, 倉島昭彦, 山下慎也, ほか：前交通動脈瘤手術 における hypothalamic artery温存のための検討. No Shinkei Geka 35(9): 881-885, 2007

9）佐野公俊：前交通動脈痛の手術. No Shinkei Geka 28(1)：916,2000

10）澤田元史，八十川雄図，岩間 亭：未破裂前交通動脈癌へ のより安全な手術アプローチ一瘤の突出方向による手術法 の選択一. 脳卒中の外科 39: 449-453, 2011

11) Sekhar LN, Natarajan SK, Britz GW, et al: Microsurgical management of anterior communicating artery aneurysms. Neurosurgery 61(5 Suppl 2): 273-292, 2007

12) Suzuki M, Fujisawa H, Ishihara $H$, et al: Side selection of pterional approach for anterior communicating artery aneurysms--surgical anatomy and strategy. Acta Neurochir (Wien) 150: 31-39, 2008

13）鈴木倫保, 小川 彰, 嘉山孝正, ほか：前交通勤脈瘤に伴 う血管奇形. No Shinkei Geka 16: 498-502, 1988

14) The UCAS Japan Investigators: The Natural Course of Unruptured Cerebral Aneurysms in a Japanese Cohort. $N$ Engl J Med 366: 2474-2482, 2012

15) Yasargil MG, Fox JL, Ray MW: The operative approach to aneurysms of the anterior communicating artery, in Krayenbühl H (ed): Advances and Technical Standards in Neurosurgery, Vol 2. Springer, Wien, 1975, pp113-170

16）安井信之：手術手技. 山浦 晶（編）：脳動脈瘤の外科一 Standard and Modified Techniques. 1I. Standard Techniques 5. 前大脳動脈, 医学書院, 東京, 1995, pp122-131

17）米川泰弘：脳神経外科手術手技に関する私見とその歴史的 背景, 3. 脳動 脈 瘤: Anterior Circulation-Pterional Approach. No Shinkei Geka 35(7): 703-718, 2007 